\title{
The Environmental Cost of Antigua and Barbuda's Diplomatic Relationship with China
}

\author{
By Frances Fuller \\ Kings College, London
}

This is an edited version of a longer paper. The full version can be obtained by contacting the author.

Much of China's interaction with large developing countries, such as within Africa and South America, has been well documented due to China's huge appetite for natural resources to support their economic growth (Saich, 2011). With the exception of the issue of the 'One China' policy and Taiwan, a neglected theme throughout literature has been China's policy and influence towards small developing nations especially towards small island developing states (SIDS) like Antigua and Barbuda (AG). The recent increase in the level of Chinese attention in the small island nation of $A G$ has piqued the interest of many. From the perspective of SIDS the implications of this developing diplomatic relationship could not only be extensive but could also be very important for the future of both national and international environmental standing as China appears to not have received much in return so far (Fieser, 2011). This has become a concern because AG lacks any natural resources of significance and no country gives financial aid without it being ultimately beneficial to them and the result could be very detrimental to $A G$.

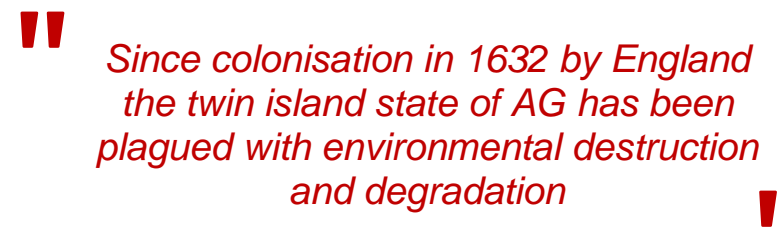

\section{The Caribbean as a hotspot for biodiversity}

Since the beginning of colonisation in 1632 by England (Albuquerque and McElroy, 1995) the twin island state of $A G$ has been plagued with environmental destruction and degradation through the conversion of the natural vegetation into tobacco, cotton and sugar plantations and as a result $A G$ and the Caribbean region as a whole currently maintains only $11.3 \%$ of its original biological habitat (Mittermeier et al., 1999). Even with this historical degradation, the Caribbean region and AG in particular have been highlighted in numerous reports and multilateral environmental agreements (MEAs) as having high levels of endemism, high numbers of species per unit area and many regionally important habitats. Therefore as a region the Caribbean "could arguably be considered the highest-priority hotspots of all" (Mittermeier et al.,1999: 53) for biodiversity conservation within any global strategy (GoAB, 2008; Sullivan Sealey and Bustamante, 1999). Further, there is a strong economic dependence on the important linkages between the terrestrial and marine environments (Conway and Lorah, 1995) and conservation should therefore be of high priority within any government agenda. AG unfortunately lacks protected areas and even the areas that are under protection suffer from a major lack of monitoring, regulation and enforcement (Albuquerque and McElroy, 1995). Today the main contributor to AG's GDP is the tourism sector which 
again, more often than not, is associated with severe environmental degradation due to unregulated development and lack of monitoring and enforcement by government institutions. There are over forty pieces of legislation in AG that govern different aspects of the environment yet most of this legislation "is out-dated and needs to be reassembled and realigned in a more coherent manner, and does not reflect the changes required by the regional and international Conventions to which the country is Party" (GoAB, 2008: 17).

\section{The example of $A G$ changing its position at the International Whaling Commission (IWC) as a result of financial aid received from Japan is a telling case.}

Further, there is a weak civil society with low levels of environmental awareness and poorly developed coordination between government and NGOs (GoAB, 2008). Historically there have been two main NGOs that have been active within the field of the environment with the Environmental Awareness Group (EAG) as the only one involved actively in education and awareness. The weak national agenda to protect AG's environment is in direct contradiction to AG's strong standing in the international community regarding to its involvement with the majority of multilateral environmental agreements (MEAs). As a small developing country, AG is not only vulnerable to the impacts of global environmental change, but is a minor contributor to these problems. Yet, as a member of the Organisation of Eastern Caribbean States (OECS), the Caribbean Community (CARICOM), the Alliance of Small Island States (AOSIS), the Group of 77 and China, and Group of Latin America and Caribbean Countries (GRULAC)1 among others, AG is at the forefront of many environmental MEAs including climate change negotiations representing the most vulnerable. This position has unfortunately been compromised in the past as a result of financial aid provided by other countries.

\section{Political turnarounds due to aid}

The example of $A G$ changing its position at the International Whaling Commission (IWC) as a result of financial aid received from Japan is a telling case. When AG joined the IWC in 1982, AG was at the forefront of the fight to put a world-wide ban on international commercial whaling and was "the only Caribbean country to vote in favour of the Southern Ocean Whale Sanctuary in 1994" (Caribbean Whale Friends, 2011). However, financial aid from the Japanese Government in the form of several large fisheries complexes, altered the Government of Antigua and Barbuda's (GoAB) position when voting at the IWC. In the late 1990s, AG switched its position to pro-whaling, a 180 degree turn around, to support Japans whaling policies whereby "ninety-two of the ninety-seven votes taken by Antigua and Barbuda since 1997 have been identical to Japan's votes" (Caribbean Whale Friends, 2011). The Prime Minister of AG, the Hon. Baldwin Spencer, stated that the financial aid received from Japan "has a direct relationship with the IWC". Further, the leader of the opposition and previous Prime Minister of AG, Hon. Lester Bird, stated nonchalantly "they don't have to buy our support for whaling, Japan is the one that does that" when speaking on China's influence on AG's foreign policy. If AG can change its position at the IWC as a result of financial aid received from the Government of Japan, it is arguable this could also occur within other international agreements in which a donor country has its own agenda, for example China. 


\section{China and Antigua \& Barbuda}

AG established diplomatic relations with China in 1983, soon after independence from the British Empire in 1981. Over the following decades the economic and political power of China has been ever increasing, as has its interest within the Caribbean region and Latin America. China generally promotes a 'dollar diplomacy' throughout the Caribbean and traditionally in exchange these countries which have good diplomatic relations with China, side with China with regards to the 'One-China' policy within the United Nations (Sutter, 2010). Recently there has been an increase in Chinese aid in the form of loans and grants, received for developmental projects in $A G$ and the broader Caribbean and Latin American region (Erikson, 2005; Sutter, 2010). When these figures are put as a percentage of GDP they are extremely high (UN ECLAC, 2010), especially when considering the value of what China is apparently receiving in return i.e. The 'One-China' Policy. Professor Terrence Wesley-Smith of the Centre for Pacific Islands Studies at University of Hawaii at Manoa stated that "China is active everywhere on the globe and it's active everywhere in pursuit of its own interests - for the most part those interests are economic ... It's in Africa because there are resources; it's in the Middle East because it needs oil and so on and so forth. There are practical reasons for China to be active all over the world" (cited in Reeves, 2008). Despite this growing activity by China, there has been little to no detailed examination of the discourses emerging around China's interest in small islands nations like AG which have no recognised natural resources of interest (Potter, Barker, Conway and Klak, 2004) beneficial for China's economic development.

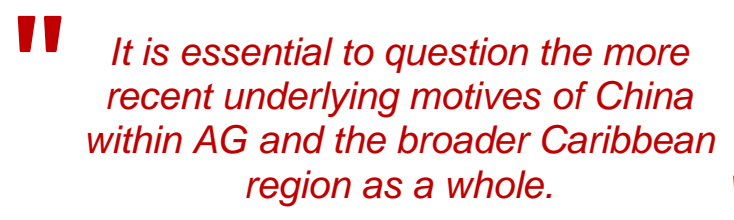

It is essential to question the more recent underlying motives of China within $A G$ and the broader Caribbean region as a whole as we move into a world where natural resources are becoming more scarce and the pressures on emerging economies such as China to combat environmental problems such as climate change are ever increasing. This research is important as the underlying reasons around the financial aid from China into AG, and other small island developing states (SIDS) with no significant natural resources have not been examined and this could have negative implications for AG. Any significant findings of the research could ultimately feed into decision making in $A G$ in future bilateral agreements with China and other foreign aid donors and add to the evolving discourse around China and the changing global geopolitical relations.

\section{China as a Benign Dragon?}

As the previous Prime Minister of AG, Hon. Lester Bird stated, the public "have a legitimate right to be concerned and here they are pumping all this money, airports, hospitals, for what? Because no country does anything that is not in its own national interest." From this study it is apparent that the nature of the manner in which China deals with SIDS like AG, is an issue but it is not the only one. One of the major themes raised in the interviews conducted was that $A G$ is a country in major debt and both the current and previous Prime Minsters argued, AG needs financial aid. The Prime Minster of AG Hon. Baldwin Spencer, stated "if it wasn't China, it would have to be somebody else", where conditionalities are usually tied to financial and therefore China 
is currently the preferred partner for financial aid. Although Baker (1998: 107) argues that for small developing countries these "links with their big neighbours are essential to their survival" (Baker, 1998: 107), there is a major need for sustainable partnerships regarding financial aid to allow for sustainable development within SIDS (Conway and Lorah, 1995).

A major concern is that AG leaders and policy makers do not have time to specialise in all areas of the decision making process, particularly the scientific and technical aspect and their motivations therefore lie mostly in the short-term financial gains and the ability to create growth opportunities. It is especially difficult for them to appreciate the physicalities of the environmental issue at hand when they are being lobbied more strongly by industry, investors and foreign partners. The scientific arguments are therefore shrouded in misconstruction of the debate, and erroneous projections of environmentally sound activities.

\section{The evolving diplomatic and now financial relations between $A G$ and China has been able to give the Government of $A B$ space to manoeuvre.}

The evolving diplomatic and now financial relations between $A G$ and China has, to date, been able to give the Government of $A B$ space to manoeuvre at a time where they are financially constrained. This financial aid has allowed Governments of $A G$ and the wider Caribbean region to finance big developmental projects and subsequently create employment for their public, which is essential for retaining political power. As Sir Sanders argues, this relationship so far has proven beneficial for Caribbean Governments but has not yet proven to be beneficial for $A G$ and the Caribbean region. One of the major issues with the developing discourse around China being a neocolonial power is that much of what has been written on the subject has come from a Western perspective. There is a need for literature on this issue from a perspective other than the 'North' and until then the question of whether China is or is becoming a neocolonial power will be open for debate.

\section{Development and the environment}

The question therefore is, how does a SIDS like AG that is in need of financial aid move along the developmental path without degrading the environment. As Baker (1998: 118) argues "many of the ex-colonial small states, are still configuring themselves as nations" and awareness and priority given to environmental issues is unfortunately low. Change is slowly happening within government agencies that govern natural resources, especially within the Environment Division. AG is the first country within the eastern Caribbean to receive a fullsize Global Environment Facility funded project, Sustainble Island Resource Management Mechanism, responsible for capacity building and implementing institutional change, "developing and implementing a comprehensive cross-sectoral ecosystem approach" (GoAB, 2008: 1). The Environment Division also implements several other developmental projects with an environmental focus with similar outcomes. Further, according to the draft National Energy Policy the AG Government is going to "amend the existing legislation in order to allow civil society to auto-generate electricity utilising renewable energy sources" (GoAB, 2010: 25) as currently doing so is against the law.

At a regional level the members of the OECS are developing Eastern Caribbean Environment Charter (ECEC) and adopting an Eastern Caribbean Environment Management Strategy (ECEMS) (GoAB, 2008: 19) which will work in line with the mandated St. George's Declaration (20 principles for environmental sustainability adopted 
by the member states of the OECS in 2000). These national and regional intentions are all steps toward a more sustainable future for the environment of AG, but it is essential that they are backed up by political will to allow the agencies that govern environmental issues in AG to develop both institutional and legislative capacity. With no change on the ground, the cycle of environmental degradation will remain.

\section{Challenges to a small nation with limited capacities}

From this study it became apparent that the majority of projects implemented with financing from China do not correlate with national and regional environmental policies. It is therefore necessary to implement projects financed by China or other donors, in AG with an integrated approach that falls in line with the policies currently under implementation within each of the government agencies, especially those that have the responsibility of managing natural resources. Furthermore it is essential to request environmentally friendly technology that is in line with the new energy desk's policies, as the Hon. Lester Bird stated that "clearly we should have had this as the basis for the agreement". It is essential that the basis of the agreements between the GoAB and China should be made public knowledge and transparent to ensure the public is aware what the Government is agreeing to on behalf of them. In the past China has been accused of lack of transparency when developing diplomatic relations with developing countries (San Jose Embassy Cable, 2009) and within a vulnerable SIDS, it is essential that this does not occur.

As Sir Sanders recommends it would be beneficial to the CARICOM region if CARICOM had a coordinated position with regards to China and as a region they would be able to see tangible benefits over a set period of time and in a predictable way. This study argues along the same lines as Wesley-Smith, that it is extremely important within an ever globalising world that SIDS need to maintain their autonomy over their natural resources (Reeves, 2008) ensuring that leaders within these states take charge of their future and allow for healthy ecosystem functions for the future generations.

All of the institutional issues outlined in the paper above, allow for foreign powers such as China to be able to take advantage of SIDS like AG. As argued by Professor Aswani (cited in Reeves, 2008) "where land mass is limited and leaders exert a disproportionate influence, countries become vulnerable to the whims of external forces ... They're making deals to the detriment of the environment and to the detriment of their people."

It is therefore essential that the proposed national and regional intentions are fully implemented and are in line with AG's international environmental commitments. Further to this it is essential that the Attorney General and Ministers back the agencies that govern natural resources within the twin island state to allow them to do their job as prescribed by national law and international conventions. This will allow for fines stipulated in legislation to feed back into and assist the agencies in areas in which they lack institutional capacity, reducing the need to rely on external financial aid from donor countries such as China. This will also allow for Ministers to see the financial benefits accrued by environmental protection for not only his/her Ministry but also for their constituency. Finally conservation and environmental education, and public awareness for the public and leaders needs to be a top priority for change to occur. 


\section{End Notes}

${ }^{1}$ These groupings or blocs of countries are important for a small developing state like AG. With a coordinated common position, the voice of many is much stronger when negotiating in the international community than by itself.

\section{References}

Albuquerque, K. de and McElroy, J.L. (1995). Antigua and Barbuda: A Legacy of Environmental Degradation, Policy Failure, and Coastal Decline. Environmental and Natural Resources Policy and Training Project EPAT/MUCIA, United States Agency for International Development (USAID) July 1995. Supplementary Paper No.5.

Baker, R. (1998). Small, isolated states in a rapidly reconfiguring world: challenge, threat or incentive? Public Administration and Development, 18: 107-122.

Caribbean Whale Friends (2011). Available at: <http://www.caribbeanwhalefriends.org/ country_1.html>. Accessed August 17th 2011.

Conway, D. and Lorah, P. (1995). Environmental protection policies in Caribbean small islands: some St Lucian examples. Caribbean Geography, 6: 16-27.

Erikson, D. P. (2005). China in the Caribbean: A Benign Dragon? FOCAL, 4 (5): 1-9.

Fieser, E. (2011). Why is China investing Billions in the Caribbean? Global Post [online]. Published 22nd April 2011. Available at:

<http://www.globalpost.com/dispatch/news/regions/americas/110325/china-caribbeaninvestment-tourism?page=0,1>. Accessed 24th May 2011.

GoAB (2008). Demonstrating the Development and Implementation of a Sustainable Island Resource Management Mechanism in a Small Island Developing State (SIRMM). Environment Division, Government of Antigua and Barbuda. UNDP Project Document.

GoAB (2010). DRAFT National Energy Policy. Office of the Prime Minister, Government of Antigua and Barbuda. December 2010.

Mittermeier R. et al. (1999). Hotspots: Earth's Biologically Richest and Most Endangered Terrestrial Ecoregions. Mexico City: CEMEX: Conservation International.

Potter, R. B., Barker, D., Conway D., and Klak, T. (2004). The Contemporary Caribbean. Harlow: Pearson Education Ltd.

Reeves, R. (2008). China Brings Austerity to Laid-Back Rarotonga: Islanders, academics question Chinese motives in Pacific. Pacific Islands Report, Pacific Islands Development Program/East-West Center [online]. Published July 16th 2008. Available at: <http://archives. pireport.org/archive/2008/July/07-16-ft.htm>. Accessed August 13th 2011.

Saich, T. (2011). Governance and Politics of China. 3rd ed. Basingstoke: Palgrave Macmillan.

San Jose Embassy Cable (2009). "Costa Rica and China Explore an Evolving 
Relationship". Cable Reference: \#09SANJOSE985. Cable time - 9 December 2009. Published 4 March 2011. Available at:

<http://cablegatesearch.net/cable.php?id=09SANJOSE985\&q=china\%20costa\%20inves tment\%20rica>. Accessed $17^{\text {th }}$ July 2011.

Sullivan Sealey, K. and Bustamante, G. (1999). Setting Geographic Priorities for Marin Conservation in Latin America and the Caribbean. Arlington, Virginia: The Nature Conservancy.

Sutter, R.G. (2010). Chinese Foreign Relations: Power and Policy since the Cold War. 2nd ed. Plymouth: Rowman \& Littlefield Publishers, Inc.

United Nations Economic Commission for Latin America and the Caribbean (UN ECLAC) (2010). Foreign Direct Investment in Latin America and the Caribbean. Briefing Paper. Unit on Investment and Corporation Strategies of the ECLAC Division of Production, Productivity and Management. United Nations: New York and Geneva.

Frances Fuller completed her MA in Environment, Politics and Globalisation at King's College London where she achieved Distinction. This paper is a shortened version of her dissertation. Recently she was a Special Advisor to the Environment Division for the UN Climate Change meeting in Durban, South Africa. She was responsible for negotiations for the second commitment period under the Kyoto Protocol for Antigua and Barbuda. She also assisted in the coordination of the negotiating and technical strategy with the rest of the delegation and within the Alliance of Small Island States (AOSIS). 